\title{
Researching the Possibility of Using Sediments in Forest Reclamation of Disturbed Lands
}

\author{
T. Kh. Gordeeva ${ }^{1, *}$, O. V. Malyuta ${ }^{2}$, N. M. Yatmanova ${ }^{3}$, O. S. Labatorina ${ }^{2}$, and Meyrbek \\ Uskenbay ugli Ibadullayev ${ }^{4}$ \\ ${ }^{1}$ Mari State University, Yoshkar-Ola, Russian Federation \\ ${ }^{2}$ Volga State University of Technology, Yoshkar-Ola, Russian Federation \\ ${ }^{3}$ Kazan Agricultural State University, Kazan, Russian Federation \\ 4"TCT Agro Cluster" LTD, Tashkent, Uzbekistan
}

\begin{abstract}
The research of the physico-chemical, biological and toxicological parameters of sediments and soils reclaimed by them, as well as the analysis of the growth of Scots pine seedlings, suggests that the use of sediments as a soil ameliorant at forest reclamation sites is advisable.
\end{abstract}

\section{Introduction}

During the hydrotechnical works related to cleaning the bottoms of rivers, a substantial amount of waste is generated - sediments, which accumulate in the alluvial areas, which can lead to a deterioration of the environmental situation in the disposal area of these multitonnage wastes.

Recently, the research of the possibility of economic use of sediments has been comprehensively conducted. The advisability of their use as an ameliorant in the reclamation of mechanically disturbed lands [1], for the reclamation of territories for construction [2], as an organic fertilizer on farmland is described. The use of sediments as an ameliorant requires the validation of their ecological safety and agrochemical value.

\section{The objective of research}

The analysis of the efficiency of the use of non-traditional ameliorants - sediments at reclamation facilities.

\section{Objects and techniques}

Field studies were carried out in the Kuyarskoye forestry of the Republic of Mari El, on the territory of a sand quarry, a subject to forest reclamation. Field and laboratory research were performed from 2010-2019

The soil in the quarry has a sandy granulometric composition, the content of physical clay does not exceed $2.44 \%$, the fraction of fine sand prevails in the soil. Agrochemical

\footnotetext{
* Corresponding author: tatiana.k.gordeeva@gmail.com
} 
parameters of soils are characterized by the following indicators: $\mathrm{pH}$ кСl - 4,71; humus $0.72 \%$; the amount of absorbed alkalines - $0.7 \mathrm{mg}$-eq. / $100 \mathrm{~g}$ of soil; mobile forms of phosphorus - $1.2 \mathrm{mg} / 100 \mathrm{~g}$; mobile forms of potassium - $1.7 \mathrm{mg} / 100 \mathrm{~g}$ of soil.

Sediments (S) were implemented into the soil of the experimental area at a dose of 60 and $120 \mathrm{t} / \mathrm{ha}$. Soil without ameliorants served as a means of monitoring. The experiment was repeated three times. After the implementation of sediments on the experimental areas, pure forest species of Scots pine were created by seedlings with an open root system.

While measuring the agrochemical parameters of soil and sediments, standard methods and techniques were used: to determine $\mathrm{pH}_{\mathrm{KCl}}$-potentiometric method; mobile phosphorus and metathetical potassium were determined by Kirsanov, hydrolitic acidity - by Kappen; the sum of metathetical chemicals $\left(\mathrm{Ca}^{+2}, \mathrm{Mg}^{+2}\right)$ - by the trilonometric method; the degree of soil saturation with alkalines - by the calculation method. Physico-chemical properties were researched by traditional methods [4]. Chemical research (atomic absorption technique) were carried out according to the ISO 11047 standard and the FSE "FCOE" methodology, with an AAnalit-400 atomic absorption spectrometer [5]. Toxicological research were conducted in accordance with the certified methods [6, 7]. The granulometric composition of soils was studied using a particle size analyzer ANALYSETT 22 MicroTes plus. Microbiological studies were carried out according to techniques generally accepted in microbiology in a soil layer of $0-20 \mathrm{~cm}$. [8]. Sowing of soil samples was conducted on elective nutrient media: putrefactors were taken into account on beef-extract agar (BEA); actinomycetes and bacteria assimilating mineral forms of nitrogen were measured on starch-ammonia agar (SAA); nitrifies - on Skerman agar medium; micromycetes - on acidified Czapek's medium; oligotrophic forms - on starvation agar (SA); autochthonous microorganisms - on nitrite agar (NA); cellulose breakers and nitrogen bacteria - by method of overgrowing soil lumps on Hutchinson's and Ashby's media, respectively. The intensity of microbiological processes of soil organic mineralization was assessed by the indices of oligotrophy (SA+NA/BEA), mineralization (SAA/BEA), microbiological transformation of crop residues (BEA+SAA) * BEA / SAA[9].

The cellulose-degrading activity of the soil was measured in the field using the application technique [10], the ammonifying activity was evaluated in laboratory conditions in accodrance with the methos of Aristovskaya T. V. [11].

The data was statistically processed using the Statisitca 6.0 software kit.

\section{Outcome and discussion}

For the field experiment, samples of sedimets with an exposure time in alluvial areas of 2 years were used as a ameliorant; their granulometric composition and content of heavy metals (HM) are presented in Tables 1-2. To evaluate the degree of contamination of sediments of HM, their gross content was measured. Since the content of HMs in sediments is not regulated by Russian regulation documents, the MPCs of soils were used for comparison [12].

Table 1. Granulometric composition of ameliorant

\begin{tabular}{|l|l|l|l|l|l|l|l|l|l|}
\hline \multirow{2}{*}{$\begin{array}{l}\text { The } \\
\text { object of } \\
\text { research }\end{array}$} & $\begin{array}{l}\text { Hydroscopic } \\
\text { moisture, \% }\end{array}$ & \multicolumn{6}{|l|}{$\begin{array}{l}\text { Fraction content, \% } \\
\text { (particles size, mm) }\end{array}$} & $\begin{array}{l}\text { Granulometric } \\
\text { composition }\end{array}$ \\
\cline { 3 - 10 } & & $\begin{array}{l}1- \\
0,25\end{array}$ & $\begin{array}{l}0,25- \\
0,05\end{array}$ & $\begin{array}{l}0,05- \\
0,01\end{array}$ & $\begin{array}{l}0,01- \\
0,005\end{array}$ & $\begin{array}{l}0,005- \\
0,001\end{array}$ & $<0,001$ & $<0,01$ & \\
\hline Sediments & 1,86 & 2,88 & 14,4 & 43,76 & 6,88 & 8,32 & 23,76 & 38,96 & $\begin{array}{l}\text { Average clay- } \\
\text { loam }\end{array}$ \\
\hline
\end{tabular}


The sediments are characterized by average clay-loam granulometic composition with a predominance of coarse dust, mud particles are about 23,76\%. The gross content of HM does not exceed the MPC in this sample.

Table 2. The content of HM in sediments (soil gross content)

\begin{tabular}{|l|l|l|l|l|l|l|}
\hline \multirow{2}{*}{$\begin{array}{l}\text { The object of } \\
\text { research }\end{array}$} & \multicolumn{6}{|l|}{ Content of HM (in ionic form), $\mathrm{mg} / \mathrm{kg}$} \\
\cline { 2 - 8 } & $\mathrm{Cu}^{2+}$ & $\mathrm{Cd}^{2+}$ & $\mathrm{Zn}^{2+}$ & $\mathrm{Fe}^{3+}$ & $\mathrm{Pb}^{2+}$ & $\mathrm{Mn}^{2+}$ \\
\hline Sediments & 11,6 & 0,41 & 23,85 & 11594,65 & 4,1 & 447,07 \\
\hline MPC & - & - & - & - & 32,0 & 1500,0 \\
\hline
\end{tabular}

The results of agro-chemical analysis showed that this sample of sediments is characterized by a alkalescent reaction of the medium, it is saturated with alkalines, the content of mobile phosphorus is very high, metathetical potassium is increased: organic substance - $2.49 \%$, mobile phosphorus - $49.7 \mathrm{mg} / \mathrm{g}$, metathetical potassium - $14.22 \mathrm{mg} /$ $100 \mathrm{~g}$, pHKCL -7.31, the sum of metathetical alkalines - $35.0 \mathrm{mg}$ eq /100 g, hydrolitic activity $-0.2 \mathrm{mg}$ eq / $100 \mathrm{~g}$, the degree of saturation with alkalines - 99.4\%.

Biotesting of the ameliorant on two test subjects (daphnia crustaceans Daphnia magna Straus and microalgaechlorella Chlorella vulgaris Beijer) revealed no toxicity for daphnia $\left(\mathrm{BCC}_{(10-48)}=1.0\right)$ and moderate toxicity for chlorella $\left(\mathrm{TDF}_{(+20 / 30-22)}=3.31\right)$

The year after the implementation of sediments into the soil, there is a considerable reduction of the acidity medium indicator, decrease of the mobile phosphorus and metathetical potassium in all versions of experiment, increase of alkaline soil saturation and moisture-holding capacity, and improvement of soil structure. All things considered, the substantial increase of HMs does not occur.

In the studied samples of the reclaimed soil, no ions of cadmium, plumbum, nickel and chromium were found within the sensitivity limit of the method used. The content of metal ions in the soil, for which there are MPC standards, is significantly less than the permitted limit values.

Toxicological experiment with use of daphnia and algae revealed no toxicity in the soils reclaimed by sediments at the reclamation facility both at a dose of $60 \mathrm{t} /$ ha and at a does of $120 \mathrm{t} / \mathrm{ha}$. However, the phyto-toxic effect of soil reclaimed by non-traditional fertilizers is reflected in inhibiting the growth of radish seedlings. Since 2012, no phytotoxicity has been observed in the versions of experiment. After two years of experiment and in subsequent years of research, water extracts from soils reclaimed by sediments do not seem toxic.

The analysis of dynamic of agro-chemical indicators for 2011-2017 showed that in the experimental site there is a tendency to decrease the humus content, phosphorus and metathetical potassium, as well as to stabilize $\mathrm{pH}$ of soil medium. (Table 3). 
Table 3. The dynamics of agro-chemical indicators, reclaimed by sediments.

\begin{tabular}{|c|c|c|c|c|c|c|c|c|c|c|c|c|}
\hline \multirow{2}{*}{$\begin{array}{l}\text { Version } \\
\text { experiment }\end{array}$} & \multicolumn{3}{|c|}{$\begin{array}{c}\text { Phosphorus, mg / } \\
\text { of }\end{array}$} & \multicolumn{3}{|c|}{$\begin{array}{c}\text { Potassium, } \\
\mathrm{mg} / 100 \mathrm{~g} \text { of soil }\end{array}$} & \multicolumn{3}{c|}{ salt extract $\mathrm{pH}$} & \multicolumn{5}{c|}{ Humus, \% } \\
\cline { 2 - 15 }$y$ & 2011 & 2015 & 2017 & 2011 & 2015 & 2017 & 2011 & 2015 & 2017 & 2011 & 2015 & 2017 \\
\hline Sediments, 60 t/ha & 3,08 & 3,00 & 0,93 & 1,5 & 2,00 & 1,36 & 5,7 & 5,73 & 6,18 & 0,38 & 0,13 & 0,14 \\
\hline Sediments, 120 t/ha & 3,16 & 3,2 & 0,98 & 2,1 & 2,23 & 1,77 & 6,79 & 6,64 & 6,80 & 0,56 & 0,19 & 0,18 \\
\hline Without fertilizers & 2,03 & 2,06 & 0,91 & 1,5 & 1,83 & 1,11 & 4,44 & 5,06 & 5,27 & 0,31 & 0,16 & 0,11 \\
\hline
\end{tabular}

The decrease in the nutrients content of soil is perhaps due to the use of these elements by plants; a decrease in the organic substance content in the soil is caused by the activity of microbes, which, given the decrease in available organic substance, use less accessible one - humus.

The research of biological activity of the soil reclaimed by sediments revealed a significant increase in the cellulose-breaking (Fig. 1) and ammonifying (Fig. 2) activities in the versions of experiments as compared with the monitoring, their maximum values are observed in the soil with the implementation of the ameliorant at a dose of $120 \mathrm{t} / \mathrm{ha}$.

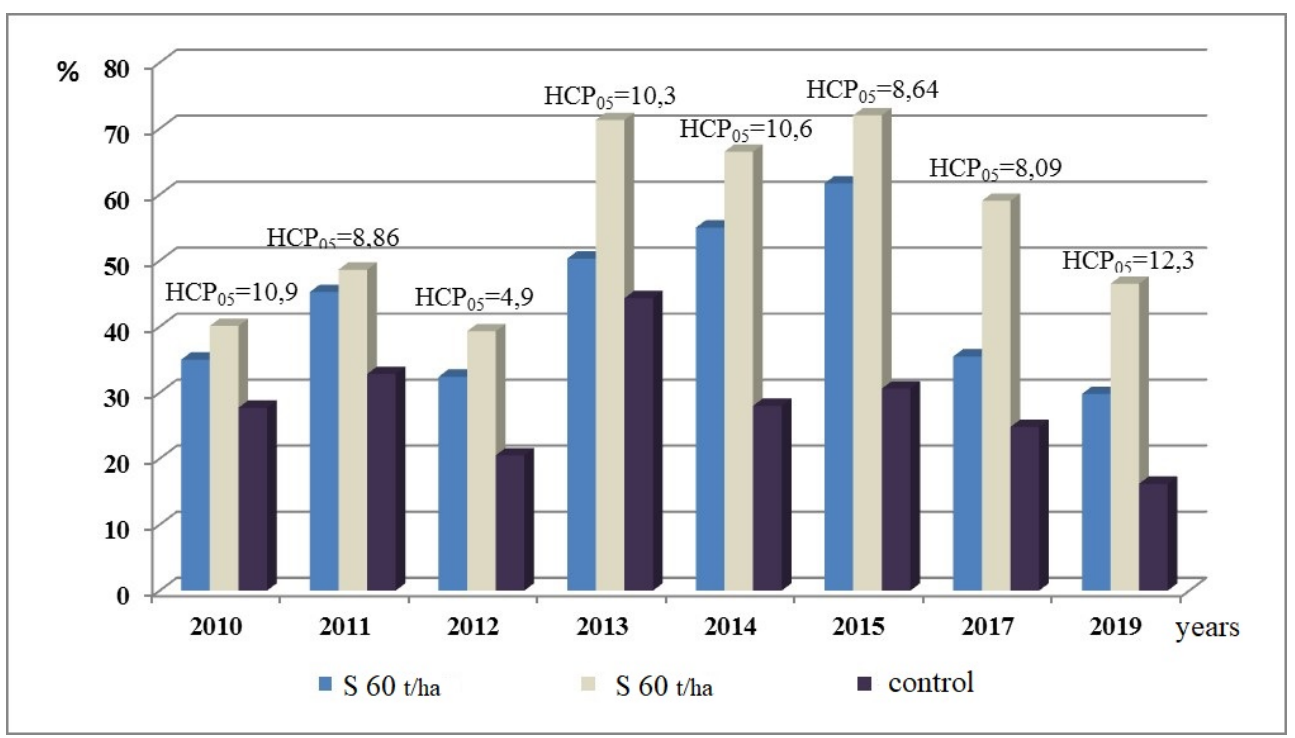

Fig. 1. The dynamics of cellulose-breaking soil activity at the reclamation facility.

The highest values of indicators of cellulose-breaking activity are observed from 2013 to 2017.

The sharp decrease of the biological activity of the soil in all versions of experiment in 2012 are probably caused by a very hot and dry summer.

Microbiological analysis showed that sediments do not have a detrimental impact on the soil microflora. The implementation of sediments in the first years of reclamation increases the number of microbes of the nitrogen cycle in comparison with unfertilized soil: ammonifiers, nitrifying and nitrogen-fixing bacteria. (Table 4). The number of microscopic 
fungi and actinomycetes in the reclaimed soil is insignificant, but it gradually increased compared to the monitoring values.

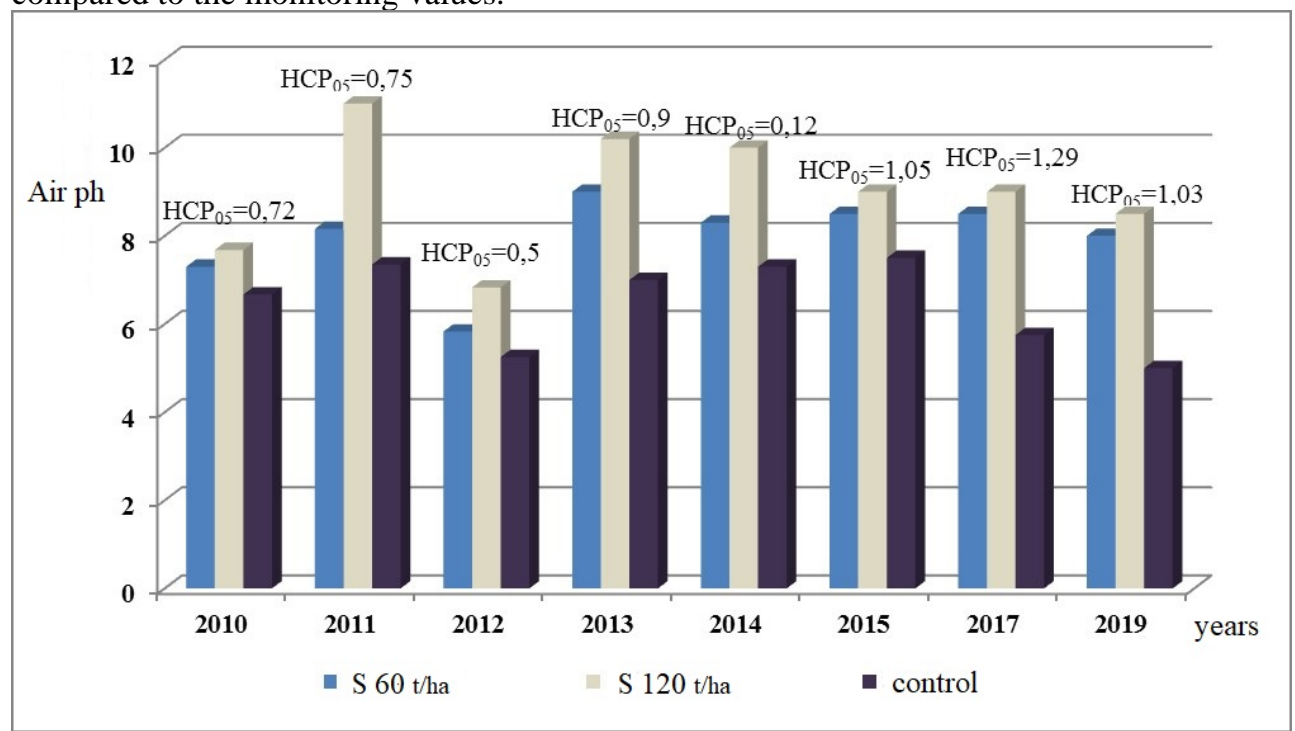

Fig. 2. The dynamics of ammonifying soil activity at the reclamation facility.

By the fifth year of reclamation, the number of hydrolytics and oligotrophs increases substantially. The oligotrophy and oligotrophilicity rate increased, and the conditional rate of humification decreases in comparison with the monitoring values - the process of transformation of soil organic substance is enhancing.

Thus, the efficiency of using sediments as an ameliorant decreases after five years of reclamation.

Table 4. The number of the main physiological groups of microbes and the activity of microbiological processes at the reclamation facility.

\begin{tabular}{|c|c|c|c|c|c|c|}
\hline \multirow[t]{2}{*}{ Microbes } & \multicolumn{2}{|c|}{ Without fertilizers } & \multicolumn{2}{|c|}{ Sediments, $60 \mathrm{t} / \mathrm{ha}$} & \multicolumn{2}{|c|}{ Sediments, $120 \mathrm{t} / \mathrm{ha}$} \\
\hline & 2011 & 2015 & 2011 & 2015 & 2011 & 2015 \\
\hline $\begin{array}{l}\text { Ammonifiers, mil. } \\
\text { cells/g of DS }\end{array}$ & $1,02 \pm 0,04$ & $1,44 \pm 0,08$ & $1,37 \pm 0,25$ & $1,24 \pm 0,09$ & $1,75 \pm 0,32$ & $3,09 \pm 0,57$ \\
\hline $\begin{array}{l}\text { Actinomycetes, } \\
\text { mil. cells / g of DS }\end{array}$ & $0,21 \pm 0,01$ & $0,22 \pm 0,03^{*}$ & $0,41 \pm 0,04$ & $0,34 \pm 0,03^{*}$ & $0,55 \pm 0,06$ & $1,3 \pm 0,11$ \\
\hline $\begin{array}{l}\text { Micromycetes, } \\
\text { k. CFU / g of DS }\end{array}$ & $7,0 \pm 0,71$ & $82,4 \pm 3,58$ & $27,5 \pm 1,44$ & $119,8 \pm 6,92$ & $19,0 \pm 1,55$ & $127,9 \pm 7,8$ \\
\hline $\begin{array}{l}\text { Nitrifying, k. cells } \\
\text { / g of DS }\end{array}$ & $0,31 \pm 0,01$ & $0,43 \pm 0,02$ & $0,39 \pm 0,03$ & $0,71 \pm 0,03$ & $0,53 \pm 0,04$ & $0,97 \pm 0,07$ \\
\hline $\begin{array}{l}\text { Cellulose- } \\
\text { breaking, \% }\end{array}$ & $5,3 \pm 0,33$ & $32,0 \pm 2,02$ & $5,0 \pm 0,98$ & $40,0 \pm 2,8$ & $7,0 \pm 1,42$ & $50,0 \pm 3,73$ \\
\hline Nitrogen-fixing, \% & $14,0 \pm 1,33$ & $13,0 \pm 1,09^{*}$ & $16,0 \pm 1,12$ & $29,3 \pm 1,98$ & $24,0 \pm 1,33$ & $69,3 \pm 4,09$ \\
\hline mineralization rate & 0,47 & 0,35 & 1,34 & 0,31 & 1,96 & 0,67 \\
\hline $\begin{array}{l}\text { oligotrophilicity } \\
\text { rate }\end{array}$ & 1,33 & 4,63 & 2,97 & 4,39 & 2,69 & 6,37 \\
\hline oligotrophy rate & 1,0 & 1,9 & 1,52 & 2,29 & 1,81 & 2,45 \\
\hline $\begin{array}{l}\text { rate of microbe } \\
\text { transformation of } \\
\text { soil organic } \\
\text { substance }\end{array}$ & 1,11 & 3,19 & 1,3 & 2,19 & 1,56 & 2,4 \\
\hline
\end{tabular}

* - differences at the $5 \%$ level of importance are not significant

** - DS - dry soil 
Analysis of the growth of Scots pine seedlings at the reclamation facility in the course of 10 years showed that 3 months after planting of seedlings, there were no significant differences in plant height. In 2012-2013, significant differences between the versions of experiment were noted for the first time: the plant height in the version with sediments 120 $\mathrm{t}$ / ha was significantly higher than the monitoring values (Fig. 3).

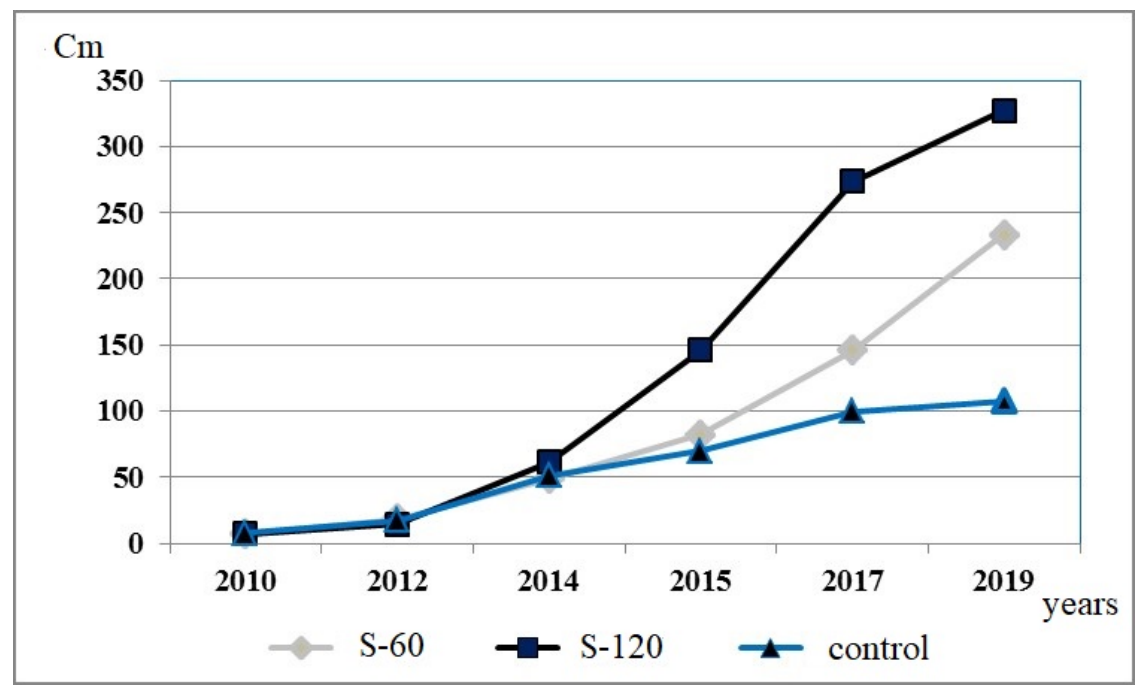

Fig. 3. The dynamics of Scots pine growth at the reclamation facility.

Since 2014, the positive dynamics remains, which indicated the presents of the most favorable soil and ecological conditions for the growth of Scots pine in the version of experiments with sediments at a dose of 120 t/ha .

\section{Conclusion}

The implementation of sediments into the soil contributes to a decrease in acidity, an increase in the soil saturation with alkalines and moisture-holding capacity, and an improvement of soil structure, although the content of nutrients in the soil rose only by a small margin.

The most favorable soil and ecological conditions for crop growth and the vital activity of soil microbiota are formed in the experimental site, reclaimed by sediments at a does of $120 \mathrm{t} / \mathrm{ha}$.

Comprehensive research showed that the use of sediments as soil ameliorants at forest reclamation facilities is advisable from an ecological standpoint.

\section{References}

1. Vetchinnikov A.A., Titova V.I., Baranov A.I., Sencheva E.V. Assessment of the possibility of using bottom sediments of the pond for reclamation of technogenically disturbed soils. Agrochemical Bulletin, 2018. No. 2. pp. 50-53.

2. Smetanin V.I. Restoration and purification of water bodies. M.: Kolos. 2003. 157 p. 
3. Chukurov D.S., Medvedeva Ya.V., Nikitin O.V. Study of the possibility of using bottom sediments of the Almetyevsk reservoir as an organic fertilizer. Russian Journal of Applied Ecology, 2016. No. 1. pp. 22-27.

4. Arinushkina, E.V. Guidance on chemical analysis of soils. E.V. Arinushkina. Moscow: Moscow State University, 1979. 487 p.

5. Technique for measuring the gross content of copper, cadmium, zinc, lead, nickel, manganese, cobalt, chromium by atomic absorption spectrometry. M.: FGU 'FTSAO' Publishing House, 2007. 20 p.

6. Environmental regulations - PND FT 14.1:2:4.12-06 (PND FT 16.1:2:3:3.9-06). Toxicological methods. Methods for determining toxicity of aqueous extracts from soils, sewage sludge and waste, drinking, waste and natural water by mortality of the Daphnia magna Straus test object. Krasnoyarsk, 2006. 46 p.

7. Environmental regulations - PND FT 14.1:2:3:4.10-04 (PND FT 16.1:2.3:3.7-04). Toxicological methods. Methods for determining toxicity of samples of surface fresh, ground, drinking, waste water, water extracts from soil, sewage sludge and waste by changing the optical density of the culture of the algae Chlorella (Chlorella vulgaris Beijer). Krasnoyarsk, 2007. 36 p.

8. Methods of soil microbiology and biochemistry / Under. ed. D. G. Zvyagintseva. Moscow: Moscow State University Publishing House, 1991.304 p.

9. Mukha V.L. On indicators reflecting intensity and direction of soil processes. Proceedings of KharSKhI. Kharkov, 1980. V. 273. pp. 12-16.

10. Methods for stationary study of soils. Ed. by A. A. Rode. Moscow: Nauka Publ., 1977. 320 p.

11. Aristovskaya T.V., Chugunova M.V. Express method for determining biological activity of soil. Pochvovedenie, 1989. No. 11. pp. 142-147.

12. Maximum permissible concentration (MPC) of chemicals in the soil: Hygienic standards. Moscow: Federal Center for Hygiene and Epidemiology of Rospotrebnadzor, 2006. 15 p. 